UDC 612.128; 612.115

doi: https://doi.org/10.15407/ubj93.05.031

\title{
OVERALL HEMOSTASIS POTENTIAL OF BLOOD PLASMA AND ITS CONNECTION TO MOLECULAR MARKERS OF THE HEMOSTASIS SYSTEM IN PATIENTS WITH STENOSIS OF CORONARY ARTERY
}

\author{
N. V. STOROZHUK ${ }^{1}$, L. V. PYROGOVA², T. M. CHERNYSHENKO', \\ O. P. KOSTYUCHENKO ${ }^{2}$, T. M. PLATONOVA ${ }^{2}$, O. B. STOROZHUK ${ }^{1}$, \\ B. G. STOROZHUK ${ }^{1}$, R. YU. MARUNICH ${ }^{2}$, \\ G. K. BEREZNYTSKY', E. M. MAKOGONENKO ${ }^{2 \bowtie}$
}

\author{
${ }^{1}$ MI Pirogov Vinnytsia National Medical University, Vinnytsia, Ukraine; \\ ${ }^{2}$ Palladin Institute of Biochemistry, National Academy of Sciences of Ukraine, Kyiv; \\ e-mail: ymakogonenko@gmail.com
}

Received: 01 April 2021; Accepted: 22 September 2021

The correlation relationships between hemostatic potential parameters and concentrations of molecular markers of the hemostasis system: soluble fibrin (sf), D-dimer (DD), fibrinogen (Fg) and protein C $(P C)$ in patients with stenosis of coronary artery 6 months after coronary angioplasty have been investigated. It was found three directions of changes in the state of the patients hemostasis system: an increasing in fibrinolytic activity $(C) \sim 18 \%$ of patients; an increasing in coagulative activity (B) $\sim 31 \%$ of patients; and maintaining of the balance between coagulation and fibrinolysis (A) $51 \%$ of patients. In patients with signs of stenosis without angina pectoris, a strong Pearson correlation was shown between the half-life of the clot and the overall hemostatic potential (OHP) $(r=0.75, P<<0.05)$, a moderate relationship between concentrations of sf and D-dimer $(r=0.67, P<0.05)$, almost complete connection between coagulation potential $(C P)$ and $\mathrm{OHP}(r=0.975, P<<0,05)$ and strong connection between $C P$ and fibrinolytic potential $(F P)(r=0.80$, $P<<0.05)$. In patients with signs of stable angina pectoris, almost complete connection was found between the concentration of sf and D-dimer $(r=0.981, P<<0.05), C P$ and OHP $(r=0.979, P<<0.05)$ and a strong connection between $C P$ and $F P(r=0.846, P<<0.05)$. Possible functional mechanisms of connection between these parameters are discussed.

Keywords: stenosis, angina pectoris, hemostasis potential of plasma, soluble fibrin, D dimer, fibrinogen.

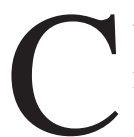

urrently the most common cause of death in the world among non-communicable disease is ischemic heart disease, which in 2019 accounted for $16 \%$ of all deaths in the world. At the same time, the increase in mortality due to this disease is growing. Thus, in the period from 2019 to 2000, mortality from it increased by more than 2 million cases and reached a total of 8.9 million cases per year. Vascular stenosis and angina are among the most dangerous ischemic diseases [1, 2]. Ischemic heart disease is caused by atherosclerosis and stenosis of the heart coronary arteries. Stenosis occurs due to narrowing in some places of the car- diac vessels. The most common cause of narrowing is atherosclerotic plaque, which blocks part of the lumen of the vessel and creates an obstacle to blood flow. Another dangerous ischemic disease is angina, the main cause of which is also atherosclerotic lesion of the coronary arteries and blood vessels of the heart of patients, which in addition to narrowing the lumen of the coronary artery is accompanied by inflammation in the endothelial wall of blood vessels $[3,4]$. In both cases, stenosis of the coronary arteries causes "wall shear stress" in the vessels [5, 6], which leads to the unfolding of Willebrand factor in the bloodstream, activation and aggregation of platelets,

(C) 2021 Storozhuk N. V. et al. This is an open-access article distributed under the terms of the Creative Commons Attribution License, which permits unrestricted use, distribution, and reproduction in any medium, provided the original author and source are credited. 
what release of procoagulant nanoparticles into the bloodstream [7, 8], which cause activation of the coagulation system with the formation of thrombin and soluble fibrin $[9,10]$, that ultimately contributes to the formation of arterial thrombi. In the coronary system, the inflammatory process stimulates the procoagulant activity of endothelial cells [11], which enhances the formation of arterial thrombi.

Our task was to determine the values of hemostatic potential and concentration of molecular markers of blood plasma hemostasis system state of patients with coronary heart disease 6 months after coronary angioplasty to identify predictors of late restenosis and angina pectoris, and to haracterize the presence and strength of the correlation between these parameters.

\section{Materials and Methods}

The study examined a group of patients of 93 persons of both sexes with stenotic lesion of the coronary artery. The diagnosis was confirmed by coronary angiography. The age of patients ranged from 42 to 76 years (mean age was 56.4 years, in patients with stenosis -56.4 years and in patients with unstable angina pectoris - 57 years). The study included patients who underwent coronary artery angioplasty with the insertion of one eluting-stent (Taxus, Boston Scientific). All patients received dual antiplatelet therapy according to the protocol, which consisted of $75 \mathrm{mg}$ of clopidogrel and $100 \mathrm{mg}$ of aspirin per day for 6 months, antihyperlipidemic therapy (rosuvastatin 10-20 mg), $\beta$-adrenoblocker (bisoprolol $5 \mathrm{mg}$ ) and ACE inhibitor (ramipril 5-10 mg). Before coronary angiography, patients underwent general clinical examinations (general blood test, creatinine, level of transaminases, total protein, bilirubin). Six months after coronagraphy (according to the unified clinical protocol of primary, secondary (specialized), tertiary (highly specialized) medical care from 02.03.2016 No 152 with changes from 23.09.2016 No 994) 44 patients were diagnosed with stable angina pectoris. At the moment of blood sampling for the study of the hemostasis system, patients did not receive anticoagulant and fibrinolytic therapy.

Permission from the Ethics Commission of Pirogov's Vinnytsia National Medical University (protocol No 12 dated 16.11.2016), and informed consent of each patient were obtained to conduct research related to blood.

Blood samples from donors and patients with signs of stenosis without angina pectoris (hereinaf- ter stenosis) and with signs of stable angina pectoris (hereinafter angina) were withdrawn in 3.8\% sodium citrate (1 part sodium citrate and 9 parts of blood, $\mathrm{pH}$ 7.4). Plasma was separated from blood cells within 1 hour after blood collection by centrifugation at $1000 \mathrm{~g}$ for $20 \mathrm{~min}$. Plasma aliquots were stored at $-20^{\circ} \mathrm{C}$.

APTT (activated partial thromboplastin time) reagent from Renam (RF), recombinant tissue plasminogen activator (t-PA) from Boehringer Ingelheim (Germany) were used in experiments. The hemostatic potential of blood plasma was determined by turbidimetric method with recording the scattering of light by a fibrin clot at $405 \mathrm{~nm}$ on a microreader Multiscan (Finland). The clot was formed in the microplate wells, to which were successively added 0.05 M HEPES buffer, $\mathrm{pH} 7.4$, containing $0.15 \mathrm{M}$ $\mathrm{NaCl}, 70 \mu \mathrm{l}$ of blood plasma, t-PA to a final concentration of $75 \mathrm{IU} / \mathrm{ml}$, (or without t-PA addition) and APTT reagent. The plasma coagulation process was initiated by the addition of $25 \mathrm{~mm} \mathrm{CaCl}$. The final volume of the reaction mixture was $300 \mu 1$ [12].

Overall hemostasis potential (OHP) was characterized by the area under the turbidity curve of the clot from the moment of initiation of plasma coagulation to the moment of complete destruction of the clot in the presence of t-PA. Coagulation potential (CP) - the area under the curve of clot formation from the moment of initiation of plasma coagulation to the moment of complete dissolution of the clot in the absence of t-PA. Fibrinolytic potential (FP) is the difference between the values of $\mathrm{CP}$ and OHP. All values were expressed in units of optical density multiplied by time in seconds (o.u.s) [12, 13].

The individual stages of the process of clot formation and hydrolysis were characterized by the following parameters: $\tau(\mathrm{s})-$ lag period, which shows the rate of activation of the internal path of the coagulation cascade, thrombin formation, fibrinogen activation into fibrin and protofibril formation; $\alpha\left(V_{1}\right)$ o.u./s - tg of the angle of inclination of the maximum rate of growth of the clot turbidity, which shows the rate of lateral association of protofibrils and the formation of fibrils; $\mathrm{H}$ (o.u.) - the magnitude of the final turbidity of the clot, which is determined by the thickness of the fibrils of the clot; L (s) is the half-life of the clot, which depends on the concentration of plasminogen, t-PA and the structure of the clot; $\beta\left(-\mathrm{V}_{2}\right)-$ o.u. $/ \mathrm{s}-\operatorname{tg}$ of the angle of inclination of the maximum rate of falling of turbidity of a clot which depends on concentration of plasmin and 
plasmin inhibitors ( $\alpha 2$-antiplasmin, PAI-1) in blood plasma [13].

The concentration of fibrinogen, soluble fibrin and $\mathrm{D}$ dimer in blood plasma was determined with enzyme-linked immunosorbent assay using test systems developed at Palladin Institute of Biochemistry of NAS of Ukraine [14, 15], and the level of protein $\mathrm{C}$ - using a test system from Renam (RF). Statistical processing of the results was performed using a standard statistical program in "Excel". The mean values of the parameters and their standard deviations were determined. The significance of the difference between the mean values of the two groups was determined by the Student's test and Pearson's pairwise correlation analysis (the Pearson correlation coefficient $-r$ ) was performed.

\section{Results and Discussion}

General characteristics of the hemostasis system in patients with stenosis and angina. To determine the parameters of the hemostatic potential of blood plasma of each patients, turbidity curves of blood coagulation processes initiated by APTT reagent in the absence and presence of t-PA were obtained. Typical experimental curves for patients with stenosis are presented in Fig. $1, A, B, C$, and for patients with angina - in Fig. 2, $A, B, C$. Analysis of the array of turbidity curves of both types of disease allowed to divide them into three groups according to the shape of the turbidity curve obtained in the presence of t-PA, namely: (A) - curves which maximum turbidity coincides with such curves in the absence of t-PA; (B) - curves which maximum turbidity exceeds that of turbidity curves in the absence of t-PA and (C) - curves with a maximum turbidity that is less than that of curves in the absence of t-PA, Fig. 1 and Fig. 2. Quantitatively, patients were divided into groups:

$\begin{array}{ccccc} & \mathrm{A} & \mathrm{B} & \mathrm{C} & \text { Total } \\ \text { Stenosis } & 22 & 18 & 9 & 49 \\ & (44.9 \%) & (36.7 \%) & (18.4 \%) & (100 \%) \\ \text { Angina } & 23 & 13 & 8 & 44 \\ & (52.3 \%) & (29.5 \%) & (18.2 \%) & (100 \%)\end{array}$

The obtained data indicate that in 44.9 and $52.3 \%$ of patients with stenosis and angina, respectively, the formation and hydrolysis of the fibrin clot in blood plasma does not differ in shape from that observed in normal blood plasma of donors, Fig. 1, $A$ and Fig. 2, A. 55.1\% with stenosis and $47.7 \%$ of patients with angina have atypical forms of turbi-
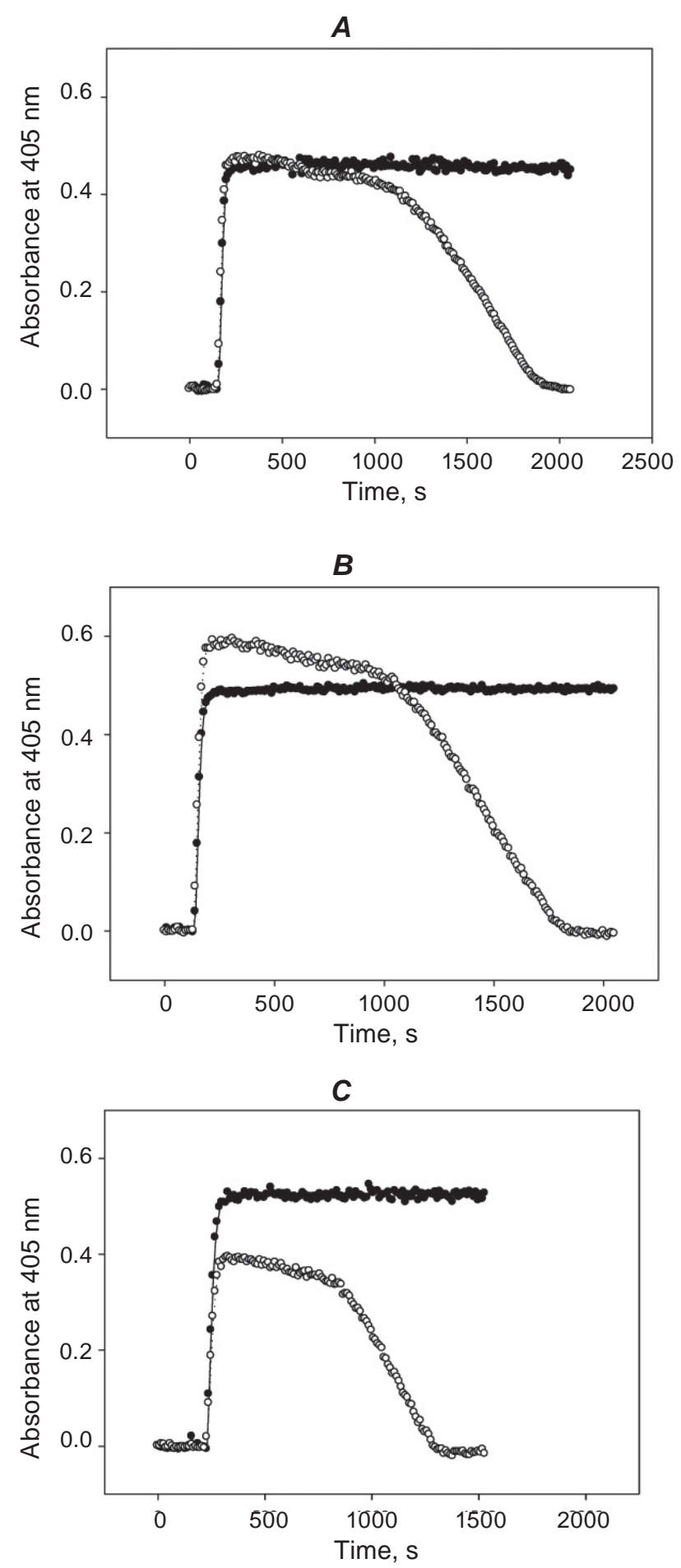

Fig. 1. Typical turbidity curves of blood plasma coagulation initiated by APTT reagent in the presence (light circle) and absence of $t-P A$ (dark circle), in patients with stenosis. A - turbidity curves of blood plasma coagulation are similar to those of donor blood plasma; $\boldsymbol{B}$ - turbidity curves of blood plasma coagulation with increased coagulation activity; $\boldsymbol{C}$ - turbidity curves of blood plasma coagulation with increased fibrinolytic activity 
dimetric curves obtained in the presence of t-PA. $36.7 \%$ and $29.5 \%$ of patients with stenosis and angina show an increased level of turbidity of the clot, which indicates increased activity of the clotting system Fig. 1, B and Fig. 2, B, and $18.4 \%$ and $18.2 \%$ of patients with stenosis and angina, respectively, show a reduced level of turbidity of the clot Fig. 1, $C$ and Fig. 2, $C$, which can be explained by the increased level of activity of the fibrinolytic system of blood plasma in these groups of patients.

The values of the parameters of turbidity curves characterizing the activation of the coagulation system $(\tau, \alpha, \mathrm{H}, \mathrm{CP})$ in group $\mathrm{A}$ of patients with stenosis and donors do not differ in the absence of t-PA, Table 1. Among the molecular markers there is a $\sim 2$ times increased level of soluble fibrin and reduced by 2 times the normal concentration of $\mathrm{D}$ dimer, which indicates a general increased coagulation and reduced fibrinolytic activity in the hemostasis system of this group of patients. In group B, in the absence of t-PA, the values of the parameters of the turbidity curve coincide with those of the donors, except for the important ratio of CP/FP $-5.96 \pm 1.32$ and $3.89 \pm 0.62$, respectively, which indicates increased activity of the coagulation system [12, 13]. This observation is confirmed by an increase in the level of soluble fibrin in 5.62 times relatively to the donor level. In the $\mathrm{C}$ group of patients where ratio of CP/FP was $3.12 \pm 0.62$, a decrease in the level of soluble fibrin, and an increase in the concentration of D-dimer indicated on increased fibrinolytic activity in this group plasmas comparing to others groups of cardiac stenosis patients.

In patients with stenosis activation of the blood plasma coagulation system is observed in all groups, but this does not cause activation of the fibrinolysis system. It is likely that the polymerization of soluble fibrin, which may occur in groups A and B, is effectively inhibited by fibrinogen (antithrombin I), the concentration of which is $~ 1.6$ times higher the concentration of Fg in donors, but is at the upper limit of normal concentration in humans, Table 1. Obviously, soluble fibrin does not form fibrin microclots and does not stimulate plasmin formation. Prolongation of the half-life of the clot in all groups of patients with stenosis in the presence of t-PA indicates an increase in the concentration of fibrinolysis inhibitors, apparently PAI-I, in blood plasma. However, the hemostatic potential ratio of $\mathrm{CP} / \mathrm{FP}$, equal to $5.96 \pm 1.32$, indicates a shift in the balance between the processes of coagulation and fibrinolysis in the
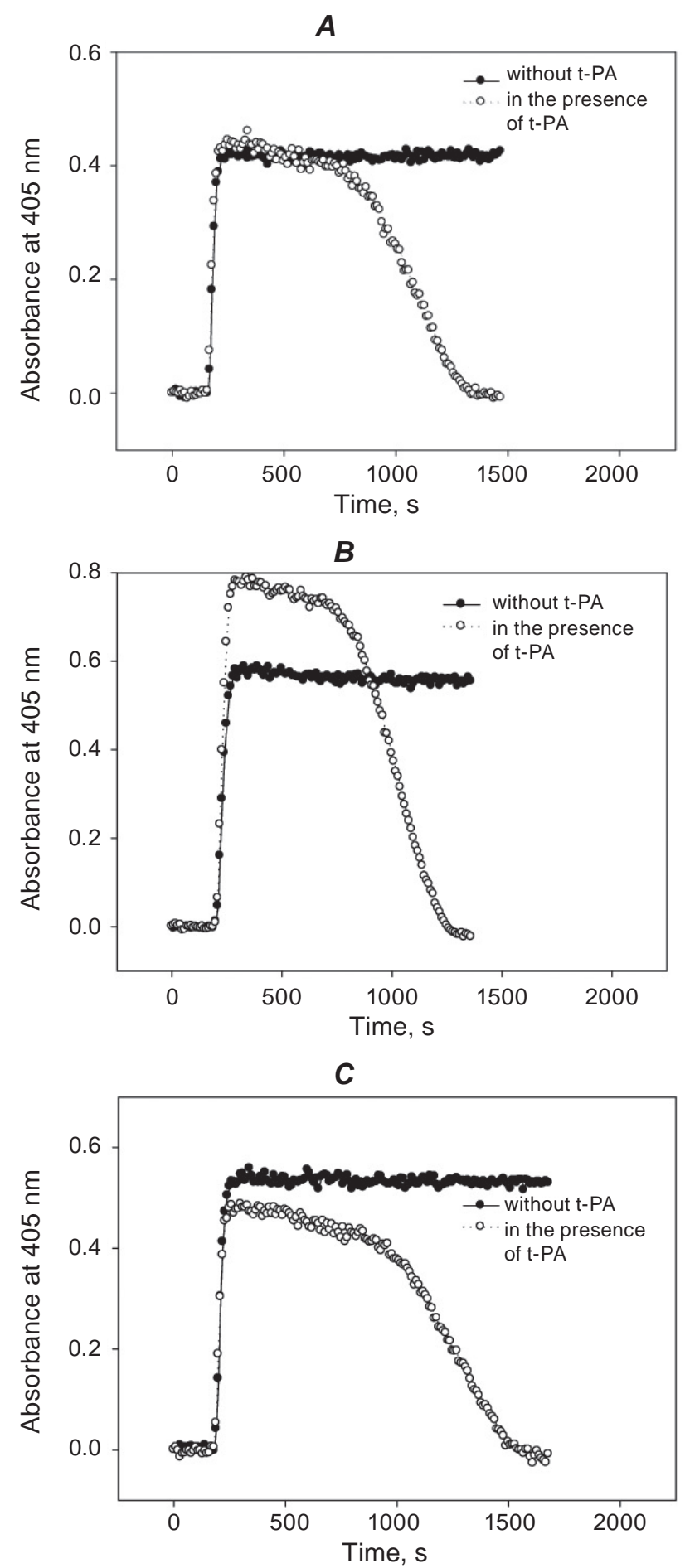

Fig. 2. Typical turbidity curves of blood plasma coagulation initiated by APTT reagent in the presence and absence of $t-P A$, in patients with angina. $\mathbf{A}-$ turbidity curves of blood plasma coagulation are similar to those of donor blood plasma; $\boldsymbol{B}$ - turbidity curves of blood plasma coagulation with increased coagulation activity; $\mathbf{C}$ - turbidity curves of blood plasma coagulation with increased fibrinolytic activity 
Table 1. Values of parameters of hemostatic potential, soluble fibrin (sf), D dimer (DD), fibrinogen (Fg) and protein $C(P C)$ in plasma of patients with stenosis $(n=49)$. Patients are divided into three subgroups depending on the shape of the turbidity curve: $A$ form -22 patients, $B$ form -18 patients, $C$ form $C-9$ patients

\begin{tabular}{|c|c|c|c|c|c|c|}
\hline & \multicolumn{4}{|c|}{ In the absence of t-PA } & \multicolumn{2}{|c|}{ In the presence of $\mathrm{t}-\mathrm{PA}$} \\
\hline Parameters & $\tau, \mathrm{s}$ & $\alpha$, o. u./s & H, o.u. & $\mathrm{CP}$, o. u.s & OHP, o. u.s & FP, o. u.s \\
\hline Donors & $140 \pm 23$ & $0,0085 \pm 0.0012$ & $0.381 \pm 0.052$ & $345 \pm 17^{*}$ & $257.5 \pm 15.0$ & $88.5 \pm 11^{*}$ \\
\hline All patients & $166 \pm 36$ & $0.0088 \pm 0.0024$ & $0.372 \pm 0.106$ & $399 \pm 245$ & $307 \pm 185$ & $92 \pm 75^{*}$ \\
\hline A Form & $134 \pm 26$ & $0.008 \pm 0.0017$ & $0.338 \pm 0.078$ & $421 \pm 243$ & $249 \pm 187^{*}$ & $100 \pm 71$ \\
\hline B Form & $156 \pm 32$ & $0.0091 \pm 0.0024$ & $0.373 \pm 0.105$ & $487 \pm 280$ & $386 \pm 227 *$ & $83 \pm 57^{*}$ \\
\hline \multirow[t]{3}{*}{ C Form } & $169 \pm 38$ & $0.0110 \pm 0.0023$ & $0.455 \pm 0.130$ & $507 \pm 208^{*}$ & $342 \pm 146$ & $167 \pm 74^{*}$ \\
\hline & n.d. & n.d. & n.d. & $\mathrm{P}=0.019$ & $\mathrm{P}=0.025$ & $\begin{array}{c}P=0.004 \\
P<0.0001 \\
\text { n.d., } \\
P<0.009\end{array}$ \\
\hline & \multicolumn{6}{|c|}{ In the presence of t-PA } \\
\hline Parameters & $\mathrm{CP} / \mathrm{FP}$ & $\tau, \mathrm{s}$ & $\alpha$, o. u./s & H, o. u. & $\mathrm{L}, \mathrm{s}$ & $\mathrm{H}_{\mathrm{o}}$, o. u. \\
\hline Donors & $3.89 \pm 0,53$ & $145 \pm 23$ & $0.0092 \pm 0.00012$ & $0.375 \pm 0.043$ & $893 \pm 31$ & $0.332 \pm 0.153$ \\
\hline All patients & $4.65 \pm 1.44^{*}$ & $167 \pm 31$ & $0.0085 \pm 0.0022$ & $0.378 \pm 0.105$ & $1137 \pm 235$ & $0.470 \pm 0.227$ \\
\hline A Form & $4.21 \pm 0.74^{*}$ & $174 \pm 26$ & $0.0080 \pm 0.0019$ & $0.340 \pm 0.078^{*}$ & $1104 \pm 228$ & $0.475 \pm 0.223$ \\
\hline B Form & $5.96 \pm 1.32 *$ & $157 \pm 33$ & $0.0091 \pm 0.0024$ & $0.411 \pm 0.115^{*}$ & $1211 \pm 256$ & $0.480 \pm 0.175$ \\
\hline \multirow[t]{3}{*}{ C Form } & $3.05 \pm 0.62 *$ & $169 \pm 38$ & $0.0092 \pm 0.0023$ & $0.402 \pm 0.127$ & $1069 \pm 184$ & $0.480 \pm 0.185$ \\
\hline & $\begin{array}{l}P=0.001 \\
P=0.001 \\
P=0.001\end{array}$ & n.d. & n.d. & $P=0.023$ & n.d. & n.d. \\
\hline & \multicolumn{2}{|c|}{ In the presence of t-PA } & \multicolumn{4}{|c|}{ Molecular markers of the hemostasis system } \\
\hline Parameters & \multicolumn{2}{|c|}{$\beta$, o. u./s } & Sf, $\mu \mathrm{g} / \mathrm{ml}$ & $\mathrm{DD}, \mathrm{ng} / \mathrm{ml}$ & $\mathrm{Fg}, \mu \mathrm{g} / \mathrm{ml}$ & $\mathrm{PC}, \%$ \\
\hline Donors & \multicolumn{2}{|c|}{$-0.00038 \pm 0.00011$} & $2.6 \pm 0.67^{*}$ & $62 \pm 16^{*}$ & $2.80 \pm 0.36^{*}$ & 100 \\
\hline All patients & \multicolumn{2}{|c|}{$-0.00027 \pm 0.00044$} & $12.8 \pm 31.2$ & $48.6 \pm 50.9$ & $4.26 \pm 1.47^{*}$ & $94.4 \pm 18.6$ \\
\hline A Form & \multicolumn{2}{|c|}{$-0.00023 \pm 0.00040$} & $14.4 \pm 32.4$ & $30.6 \pm 14.5^{*}$ & $4.27 \pm 1.38$ & $93.2 \pm 19.9$ \\
\hline B Form & \multicolumn{2}{|c|}{$-0.00031 \pm 0.00044$} & $14.7 \pm 37.78$ & $61.2 \pm 58.8$ & $4.19 \pm 1.66$ & $97.4 \pm 19.2$ \\
\hline \multirow[t]{2}{*}{ C Form } & \multicolumn{2}{|c|}{$-0.00028 \pm 0.00045$} & $5.29 \pm 3.26^{*}$ & $67.00 \pm 7.77^{*}$ & $4.40 \pm 1.42^{*}$ & $91.3 \pm 14.7$ \\
\hline & \multicolumn{2}{|r|}{ n.d. } & $P=0.015$ & $\begin{array}{l}P=0.001 \\
P=0.001\end{array}$ & $\begin{array}{l}P=0.002 \\
P=0.002\end{array}$ & n.d. \\
\hline
\end{tabular}

n.d. - There is not a statistically significant difference between the mean values of each of the two groups; *statistically significant difference between the mean values of indicated groups

direction of coagulation only for patients in group B. In group $\mathrm{A}$, the balance between coagulation and fibrinolysis (4.21 \pm 0.74$)$, is maintained. In group C, the equilibrium is shifted toward fibrinolysis and the ratio is $3.12 \pm 0.62$, respectively (donors $-3.89 \pm 0.53$ [13]). It should be noted that the difference in the phenomenology of turbidity curves in patients of groups $\mathrm{B}$ and $\mathrm{C}$ reflects the opposite directions of changes in the state of hemostasis of blood plasma in these groups of patients.

Thus, the shape of the turbidity curve indicates in the case of patients with stenosis (group A) an increased level of activation of the blood coagulation system and slight shifts in the balance between $\mathrm{CP}$ and FP (4.21 \pm 0.74$)$ towards coagulation. In the case of patients of group B there is an activation of 
the blood plasma coagulation system and a significant shift of the balance between CP and FP in the direction of activation of the coagulation system $(5.96 \pm 1.32)$. In case $C$, there is a significant shift in the balance between the processes of coagulation and fibrinolysis in the direction of activation of the latter (3.05 \pm 0.65$)$.

The values of the parameters of turbidity curves that characterize the activation of the coagulation system $(\tau, \alpha, \mathrm{H}, \mathrm{CP})$ in group A of patients with angina and donors are given in Table. 2. The rate of fibrinogen activation and protofibril formation slows down 1.29-1.38 times in patients of group $\mathrm{A}$ and group $\mathrm{B}$. In the presence of t-PA, the rate of protofibril formation and the rate of clot half-life are decreased by 1.24 times. However, the rate of dissolution of the clot structure $(\beta)$ in the plasma of patients of all groups increases $\sim 2$ times. The ratio of CP/FP in the groups of patients with angina is in group $A-4.65 \pm 1.51$, in group $B-7.05 \pm 2.79$, in group $\mathrm{C}-2.90 \pm 0.32$, which indicates a shift in equilibrium in the direction of blood plasma clotting in group B and in fibrinolysis - in group C. It should be noted a lower concentration of soluble fibrin in the blood plasma of all groups of patients with angina compared with those in patients with stenosis and a lower concentration of D-dimer in group C. There are also little differences in the plasma concentrations of Fg and PC in patients of the corresponding groups with stenosis and angina. It should also be noted the increased level of initial turbidity in the blood plasma of all groups in stenosis by 1.44 and angina 1.59 times higher those of the blood plasma of donors, which in units of optical density is 0.138 and 0.202 at $405 \mathrm{~nm}$, respectively. It can be assumed that these values indicate the presence in the plasma of patients nanoparticles, which are released into the blood by platelets, monocytes, endothelial cells [9] at the sites in the affected coronary artery with stenosis or angina and may indicate the degree of vascular damage. The rate of lateral association of protofibrils $(\alpha)$ for patients with stenosis and angina does not differ. However, the rate of destruction of the structure of the clot $(\beta)$ in the plasma of patients with stenosis is much higher than in the plasma of patients with angina, respectively (stenosis/angina): in group $\mathrm{A}-0.63 \cdot 10^{-3} / 0.23 \cdot 10^{-3}=2.7$; in group $\mathrm{B}-0.58 \cdot 10^{-3} / 0.31 \cdot 10^{-3}=1.9$; in group $\mathrm{C}-$ $0.51 \cdot 10^{-3} / 0.28 \cdot 10^{-3}=1.6$ times. It has previously been shown that in a pure protein system, the half-life of a clot depends on the plasmin concentration [16]. Since the half-life of the clot in plasma of patients with ste- nosis and angina did not differ, the concentration of plasmin formed in both cases should be the same, indicating the same rate of plasminogen activation in both clots. Inhibition of the process of clot destruction by plasmin indicates a higher concentration of plasmin inhibitors, possibly covalently incorporated by factor XIIIa into the structure of the clot [17], and those ( $\alpha 2$-antiplasmin, PAI-1) presented in the blood plasma of patients with stenosis. This may be due to the presence of wall shear stress, which increases the population of activated platelets, which together with procoagulant nanoparticles release plasmin inhibitors into the bloodstream [18].

Thus, changes in the parameters of turbidity curves of formation and dissolution of fibrin clot in blood plasma, hemostatic potentials and concentrations of molecular markers of hemostasis system state in patients with stenosis and angina are similar at these diseases and indicate three directions of changes in the state of the hemostasis system: an increase in fibrinolysis (C) $\sim 18 \%$ of patients; an increase in coagulation (B) $\sim 31 \%$ of patients; and maintaining a balance between coagulation and fibrinolysis (A) $\sim 51 \%$ of patients.

Analysis of the values of the turbidity curves parameters and the concentrations of molecular markers of the state of the hemostasis system showed similar directions of their changes in patients with both diseases. In this regard, it was important to investigate the presence and strength of correlations between functionally related parameters of the hemostasis system in the entire group and subgroups of patients separately, which was estimated by the value of Pearson's correlation coefficient [13]. The studied parameters were divided into three groups: the first one included the parameters of the turbodity curve of formation and dissolution of the fibrin clot $(\tau, \alpha, \beta, H)$; to the second - coagulation, overall and fibrinolytic potentials (CP, OHP and FP), and the third - the concentration of molecular markers of the hemostasis system (Fg, PC, D dimer, sf).

In case of stenosis in the first group of parameters of the turbidity curve no significant correlation was found between $\tau, \alpha, \mathrm{H}$ and $\beta$ parameters in the absence and presence of t-PA, both within the group and with concentrations of molecular markers - Fg, PC, D dimer and sf. In group B patients, a strong correlation was found in the pairs LOHP and (L- $\tau)-\mathrm{OHP}$ with $r=0.75$ and $r=0.76$, respectively, and $P<<0.05$ for each of the two pairs. In group $C$ of patients with stenosis for the third group of parameters revealed only one moderately 
Ta ble 2. Values of parameters of hemostatic potential, soluble fibrin (sf), D dimer (DD), fibrinogen (Fg) and protein $C(P C)$ in plasma of patients with angina pectoris $(n=44)$. Patients are divided into three subgroups depending on the shape of the turbidity curve: A form - 23 patients, $B$ form -13 patients, $C$ form -8 patients

\begin{tabular}{|c|c|c|c|c|c|c|}
\hline & \multicolumn{4}{|c|}{ In the absence of t-PA } & \multicolumn{2}{|c|}{ In the presence of t-PA } \\
\hline Parameters & $\tau, \mathrm{s}$ & $\alpha$, o. u./s & H, o.u. & CP, o. u.s & OHP, o. u.s & FP, o. u.s \\
\hline Donors & $40 \pm 23^{*}$ & $0.0085 \pm 0.0012$ & $0.381 \pm 0.052$ & $345 \pm 17$ & $257,5 \pm 15$ & $88.5 \pm 11.0^{*}$ \\
\hline All patients & $184 \pm 39 *$ & $0.0079 \pm 0.0027$ & $0.347 \pm 0.110$ & $374 \pm 161$ & $307 \pm 185$ & $90 \pm 75$ \\
\hline A Form & $180 \pm 33 *$ & $0.008 \pm 0.0017$ & $0.352 \pm 0.079$ & $388 \pm 162$ & $309 \pm 129$ & $92 \pm 49$ \\
\hline B Form & $188 \pm 128$ & $0.0080 \pm 0.0020$ & $0.367 \pm 0.156$ & $369 \pm 147$ & $384 \pm 276$ & $59 \pm 31^{*}$ \\
\hline \multirow[t]{3}{*}{ C Form } & $195 \pm 65^{*}$ & $0.0074 \pm 0.0039$ & $0.334 \pm 0.135$ & $344 \pm 191$ & $225 \pm 128$ & $119 \pm 64 *$ \\
\hline & $\begin{array}{l}P=0.008 \\
P<0.001 \\
P=0.002\end{array}$ & n.d. & n.d. & n.d. & n.d. & $\begin{array}{l}P=0.003 \\
P=0.008\end{array}$ \\
\hline & \multicolumn{6}{|c|}{ In the presence of t-PA } \\
\hline Parameters & $\mathrm{CP} / \mathrm{FP}$ & $\tau, \mathrm{s}$ & $\alpha$, o. u./s & H, o. u. & L, $\mathrm{s}$ & $\mathrm{H}_{\mathrm{o}}$, o. u. \\
\hline Donors & $3.89 \pm 0.53^{*}$ & $145 \pm 23^{*}$ & $0.0092 \pm 0.00012$ & $0.375 \pm 0.043$ & $893 \pm 31^{*}$ & $0.332 \pm 0.153^{*}$ \\
\hline All patients & $4.01 \pm 2.28$ & $185 \pm 39$ & $0.0073 \pm 0.0027$ & $0.358 \pm 0.120$ & $1137 \pm 235$ & $0.534 \pm 0.218^{*}$ \\
\hline A Form & $4.65 \pm 1.51^{*}$ & $180 \pm 33^{*}$ & $0.0082 \pm 0.0025$ & $0.363 \pm 0.109$ & $1095 \pm 234^{*}$ & $0.529 \pm 0.260 *$ \\
\hline B Form & $7.05 \pm 2.79 *$ & $189 \pm 29 *$ & $0.0087 \pm 0.0034$ & $0.419 \pm 0.171$ & $1111 \pm 288^{*}$ & $0.501 \pm 0.161 *$ \\
\hline \multirow[t]{3}{*}{ C Form } & $2.90 \pm 0.32 *$ & $195 \pm 65^{*}$ & $0.0068 \pm 0.0036$ & $0.302 \pm 0.116$ & $977 \pm 157$ & $0.528 \pm 0.182^{*}$ \\
\hline & $\begin{array}{l}P<0.001 \\
P=0.022 \\
P<0.001\end{array}$ & $\begin{array}{l}P=0.002 \\
P<0.001 \\
P=0.028\end{array}$ & n.d. & n.d. & $\begin{array}{l}P=0.006 \\
P=0.021\end{array}$ & $\begin{array}{l}P=0.020 \\
P=0.027 \\
P=0.016 \\
P=0.017\end{array}$ \\
\hline & \multicolumn{2}{|c|}{ In the presence of $t-P A$} & \multicolumn{4}{|c|}{ Molecular markers of the hemostasis system } \\
\hline Parameters & \multicolumn{2}{|c|}{$\beta$, o. u./s } & Sf, $\mu \mathrm{g} / \mathrm{ml}$ & $\mathrm{DD}, \mathrm{ng} / \mathrm{ml}$ & $\mathrm{Fg}, \mu \mathrm{g} / \mathrm{ml}$ & $\mathrm{PC}, \%$ \\
\hline Donors & \multicolumn{2}{|c|}{$-0.00038 \pm 0.00011$} & $2.60 \pm 0.67$ & $62 \pm 16^{*}$ & $2.80 \pm 0.36^{*}$ & 100 \\
\hline All patients & \multicolumn{2}{|c|}{$-0.00057 \pm 0.00027$} & $7.06 \pm 13.8$ & $60.5 \pm 131.3$ & $4.42 \pm 1.37 *$ & $93.3 \pm 16.2$ \\
\hline A Form & \multicolumn{2}{|c|}{$-0.00063 \pm 0.00040$} & $6.96 \pm 11.8$ & $85.1 \pm 131.3$ & $4.50 \pm 1.39 *$ & $92.0 \pm 19.1$ \\
\hline B Form & \multicolumn{2}{|c|}{$-0.00058 \pm 0.00039$} & $9.2 \pm 20.7$ & $40.0 \pm 31.2^{*}$ & $4.64 \pm 1.35^{*}$ & $97.6 \pm 19.1$ \\
\hline \multirow[t]{2}{*}{ C Form } & \multicolumn{2}{|c|}{$-0.00051 \pm 0.000056$} & $3.46 \pm 1.89$ & $31.6 \pm 26.5^{*}$ & $4.07 \pm 0.61^{*}$ & $89.3 \pm 12.8$ \\
\hline & \multicolumn{2}{|r|}{ n.d. } & n.d. & $\begin{array}{l}P=0.046 \\
P=0.005\end{array}$ & $\begin{array}{l}P<0.001 \\
P<0.001 \\
P<0.001 \\
P<0.001\end{array}$ & n.d. \\
\hline
\end{tabular}

n.d. - There is not a statistically significant difference between the mean values of the two groups; *statistically significant difference between mean values of the indicated groups

strong correlation between the concentration of sf and $\mathrm{D}$ dimer with $r=0.67$ and $P<0.05$. The latter result confirms our assumption about the involvement of blood cells and the transepithelial transport mechanism of removal of soluble fibrin from the bloodstream through the blood-tissue barrier in cardiac arteries stenosis $[19,20]$.
The data on the presence of a strong positive correlation between the half-life of the clot and the value of the overall hemostasis potential in patients of group B with stenosis are also noteworthy. This result indicates the dependence of activation and functioning of the fibrinolytic system in patients with increased activity of the blood plasma coagu- 
lation system on the value of OHP, which is determined by the protein composition, size and structure of fibrin clot, the formation and lysis of which in vitro is initiated by APTT reagent.

At the same time, a moderate (but quantitatively on the border of strong -0.67 and -0.7 strong) negative correlation between the length of the lag period and the half-life of the clot in patients of group $\mathrm{B}$ indicates the molecular processes that determine the protein the composition, structure, magnitude and time (rate) of the half-lysis of the clot, namely: the rate of activation of the internal coagulation pathway and thrombin formation, the rate of transformation of Fg in fibrin monomer and in parallel the same activation of factor XIII, the rate of selfassembly of fibrin in protofibrils, inclusion of $\gamma^{\prime}$ fibrin into protofibrils and crosslinking of fibrin via $\gamma-\gamma$ chains and covalent incorporation of $\alpha 2-\mathrm{AP}$ and PAI-1 fibrinolysis inhibitors into protofibrils [21, 22]. This result shows that the higher the rate of these molecular processes, the more stable the structure of the fibrin clot to lysis by the fibrinolytic system of blood plasma [23]. The negative correlation between the rate of fibrin clot formation in blood plasma and the rate of its lysis in vitro by the fibrinolytic system confirms the kinetic mechanism of regulation of hemostatic balance in blood plasma of patients with coronary arteries stenosis [23].

In angina, as in stenosis, in the first group of parameters of the turbidity curve no correlations were found within the group between the values of $\tau, \alpha, H$ parameters in the absence and presence of t-PA. In a pair of parameters $\Delta \mathrm{H}-\mathrm{FP}$ was found a strong positive correlation with $r=0.71$ and $P<0.05$ in group $C$, which was absent in other groups of patients. An increase in the value of the parameter $\Delta \mathrm{H}$ (the difference between the $\mathrm{H}$ turbidity curve obtained in the absence and presence of t-PA) indicates a decrease in the value of OHP, which is probably due to inflammation in the coronary system, leukocyte activation and release of proteolytic enzymes into the bloodstream. and among them is elastase, which cleaves $\alpha \mathrm{C}$ regions from $\mathrm{Fg}$, forming an $\mathrm{X}$ fragment that is able to accelerate Pg activation and lysis of the clot $[24,25]$. For the L- OHP pair in patient groups $\mathrm{A}$ and $\mathrm{B}$, there was a strong correlation with $r=0.72$ and 0.88 , respectively, with the same $P<<0.05$. Between the parameters - the time of dissolution of the clot $(\mathrm{L}-\tau)$ and the concentration of DD and sf was shown a weak and moderate relationship, respectively, with $r=0.46$ and $P<<0.05$ and $r=0.59$ and $P<0.05$ for patients in group A. As in the case of stenosis, in angina there is a strong correlation between the parameters $(\mathrm{L}-\tau)-\mathrm{OHP}$ in the blood plasma of patients in all groups $\mathrm{A}, \mathrm{B}$ and C with $r$ and $P$, respectively, 0.7 and $P<<0.05,0.89$ and $P<<0.05$ and 0.72 and $P=0.046$.

In contrast to patients with coronary arteries stenosis, where only in group $\mathrm{C}$ there is a moderate correlation between sf and $\mathrm{DD}$, in all patients with angina there is a correlation between sf and DD in group A almost complete with $r=0.981$ and $P<<0.05$, in group B strong with $r=0.86$ and $P<<0.05$ and in group $C$ strong correlation with $r=0.75$ and $P<<0.05$, Fig. 3. Since a strong correlation between the concentration of the main molecular markers - sf and DD, which directly reflects the balance between coagulation and fibrinolytic components of the hemostasis system in patients with angina in vivo at the time of blood sampling is observed in all patient groups, then we can assume that in the vessels of the coronary circulatory system localized a powerful system of fibrinolysis, which effectively hydrolyzes the formed sf.

However, another mechanism for balance regulation between sf and DD concentrations is possible. Given that fibrin desA, which forms sf, has a plasma half-life of 2 hours [26], and DD - 9-16 hours $[27,28]$, and that the molecular weight of fibrin desA is 1.8 times greater than this $\mathrm{DD}$, and that all $\mathrm{D}$ dimer is formed by hydrolysis of sf, to form $0.085 \mu \mathrm{g} / \mathrm{ml}$ concentration of DD must be cleaved $0.17 \mu \mathrm{g} / \mathrm{ml} \mathrm{sf}$ or $2.4 \%$ of its concentration to maintain a balanced level of concentrations that we observe in patients with angina, Table. 2 . In this case, $97.6 \%$ of sf should be removed by blood cells and vascular endothelium in the circulatory system [23, 29].

The study of correlations between hemostatic potentials in the in vitro system showed that for all patients with angina and stenosis there is an almost complete relationship between the values of coagulation and total hemostatic potential, Fig. 4 and Fig. 5. At the same time its value does not change essentially depending on group of patients. Thus, for all patients with angina $r=0.996$ with $P<<0.05$, and for groups A, B, and C, respectively, $r=0.964$ with $P<<0.05, r=0.991$ with $P<<0.05$ and $r=0.996$ with $P<<0.05$. For all patients with stenosis $r=0.979$ with $P<<0.05$ and for groups A, B, and C, respectively, $r=0.988$ with $P<<0.05, r=0.996$ with $P<<0.05$ and $r=0.973$ with $P<<0.05$. In CP - FP parameters pair, a strong relationship is maintained 

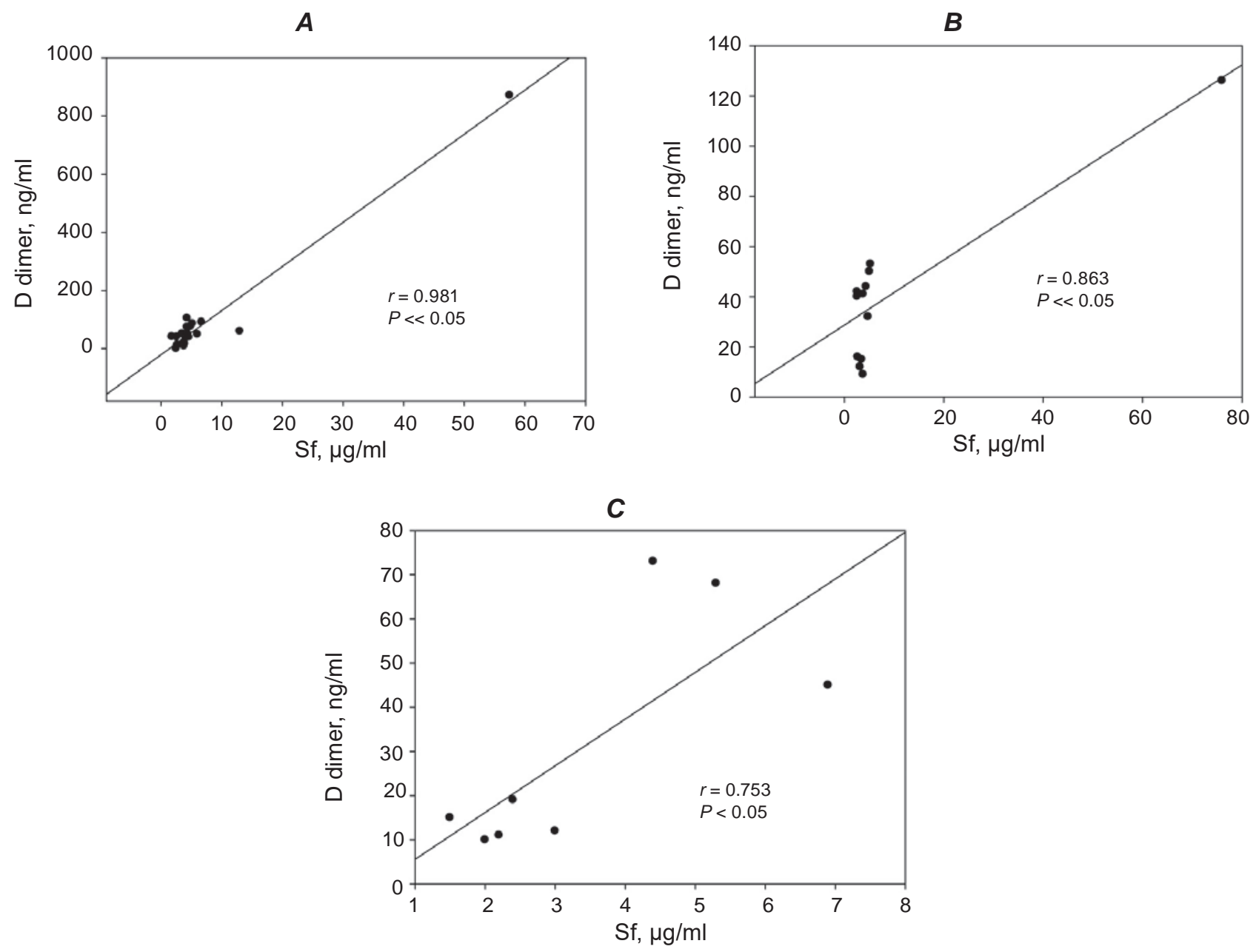

Fig. 3. Plot of Pearson correlation relationship between values of sf and $D$ dimer concentrations for angina patients of group $A(n=23)(\mathbf{A})$, group $B(n=13)(\mathbf{B})$ and group $C(n=8)(\mathbf{C})$
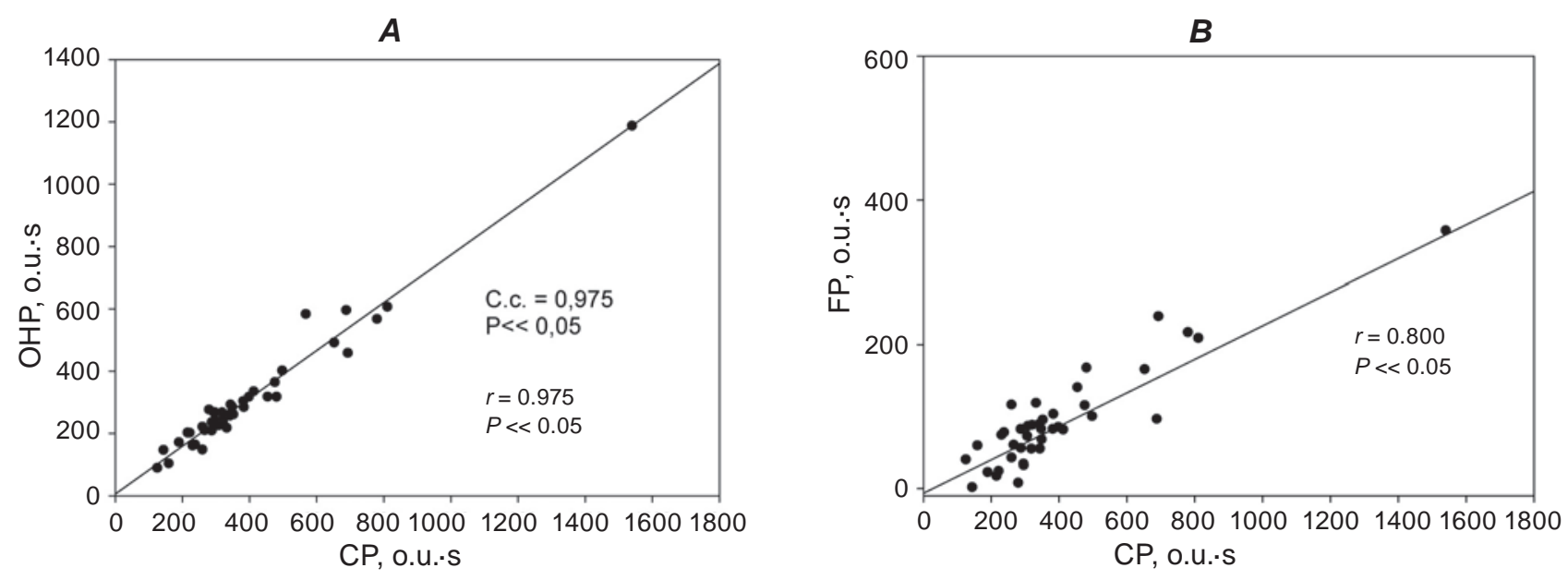

Fig. 4. Plot of Pearson correlation relationship between values of coagulation and overall hemostasis potential (A) and coagulation and fibrinolytic potential (B) of blood plasma of all patients with angina 

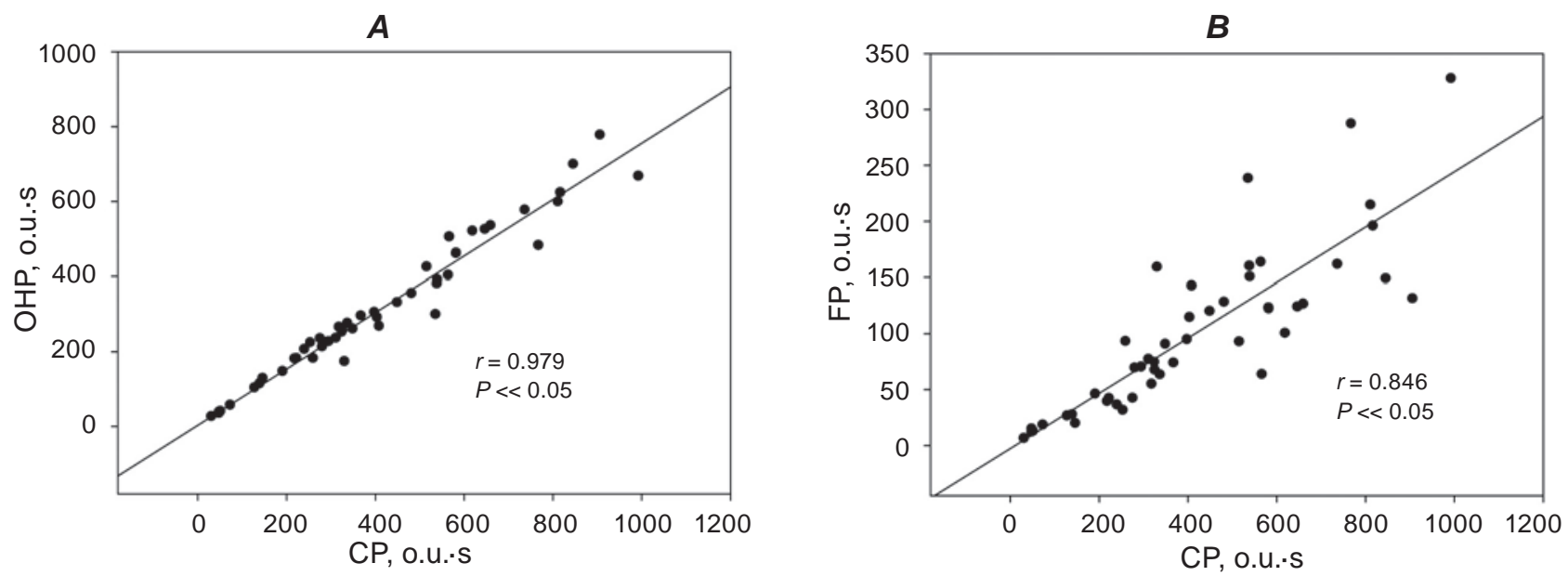

Fig. 5. Plot of Pearson correlation relationship between coagulation and overall hemostatic potential (A) and coagulation and fibrinolytic potential (B) of blood plasma of all patients with coronary stenosis

for all patients with angina and stenosis, respectively, $r=0.80$ with $P<<0.05$ and $r=0.846$ with $P<<0.05$. For all patients with stenosis for the pair OHP - FP there is a strong relationship $r=0.77$ with $P<<0.05$, and for patients with angina the strength of the relationship decreases to moderate $-r=0.67$ with $P<<0.05$.

The obtained data confirm the conclusion that the general directions of changes of coagulation and fibrinolytic parameters of the state of the hemostasis system of blood plasma of patients with stenosis and angina have similar tendencies.
Conflict of interest. Authors have completed the Unified Conflicts of Interest form at http://ukrbiochemjournal.org/wp-content/uploads/2018/12/ coi_disclosure.pdf and declare no conflict of interest.

Funding. This work was supported by theme 15 of the Palladin Institute of Biochemistry, Natinal Academy of Sciences of Ukraine, State Registration No 0117 U004344. 


\section{ЗАГАЛЬНИЙ ГЕМОСТАТИЧНИЙ \\ ПОТЕНЦАЛ ПЛАЗМИ \\ КРОВІ ТА ЙОГО ЗВ'ЯЗОК ІЗ \\ МОЛЕКУЛЯРНИМИ МАРКЕРАМИ \\ СИСТЕМИ ГЕМОСТАЗУ В \\ ПАЦІЕНТІВ ЗІ СТЕНОЗОМ КОРОНАРНОÏ АРТЕРIÏ}

\author{
Н. В. Сторожук ${ }^{1}$ Л. В. Пирогова ${ }^{2}$, \\ T. М. Черниченко $\sigma^{2}$, О. П.Костюченко ${ }^{2}$, \\ T. М. Платонова ${ }^{2}$, О. Б. Сторожук ${ }^{1}$, \\ Б. Г. Сторожук 1 , Г. К. Березницькийㄹ, \\ Є. М. Макогоненко ${ }^{2 \rrbracket}$
}

\author{
${ }^{1}$ Вінницький національний медичний \\ університет ім. М. І. Пирогова, Україна; \\ ${ }^{2}$ Інститут біохімії ім. О. В. Палладіна \\ НАН України, Київ; \\ 凹e-mail: ymakogonenko@gmail.com
}

Вивчали зв'язок між показниками гемостатичного потенціалу та концентраціями молекулярних маркерів системи гемостазу: розчинного фібрину (sf), D-димеру (DD), фібриногену (Fg) та протеїну C (PC) в пацієнтів зі стенозом коронарної артерії через 6 місяців після стентування. У хворих було виявлено три напрями зміни стану системи гемостазу: збільшення фібринолітичної активності у 18\% пацієнтів; збільшення коагуляційної активності (В) у 31\% пацієнтів; підтримка балансу між згортанням і фібринолізом (A) в $\sim 51 \%$ пацієнтів. У пацієнтів зі стенозом без ознак стенокардії продемонстровано сильну кореляцію за Пірсоном між часом напівлізису згустку та загальним гемостатичним потенціалом (ЗГП) $r=0,75, P<<0,05)$, помірна залежність між концентраціями $\mathrm{sf}-\mathrm{D}$-димер $(r=0,67$, $P<0,05)$, майже повний зв'язок між потенціалом згортання (ЗП) і ЗГП ( $r=0,975, P<<0,05)$ та сильний зв'язок між ЗП і фібринолітичним потенціалом (ФП) $(r=0,80, P<<0,05)$. У пацієнтів із ознаками стабільної стенокардії виявлено майже повний зв'язок між концентрацією sf та D-димеру $(r=0,981, P<<0,05), 3 П$ і ЗГП $(r=0,979, P<<0,05)$ та сильний зв'язок між ЗП та ФП $(r=0,846, P<<0,05)$. Обговорюються можливі функціональні механізми зв'язку між цими параметрами.

К л ю ч о в і с ло в а: стеноз коронарної артерії, гемостатичний потенціал плазми, розчинний фібрин, D-димер, фібриноген.

\section{References}

1. Marzilli M, Merz CN, Boden WE, Bonow RO, Capozza PG, Chilian WM, DeMaria AN, Guarini G, Huqi A, Morrone D, Patel MR, Weintraub WS. Obstructive coronary atherosclerosis and ischemic heart disease: an elusive link! J Am Coll Cardiol. 2012; 60(11): 951-956.

2. Pepine CJ, Douglas PS. Rethinking stable ischemic heart disease: is this the beginning of a new era? J Am Coll Cardiol. 2012; 60(11): 957959.

3. Lerman A, Zeiher AM. Endothelial function: cardiac events. Circulation. 2005; 111(3): 363368.

4. Libby P, Ridker PM, Maseri A. Inflammation and atherosclerosis. Circulation. 2002; 105(9): 1135-1143.

5. Cunningham KS, Gotlieb AI. The role of shear stress in the pathogenesis of atherosclerosis. $L a b$ Invest. 2005; 85(1): 9-23.

6. Zhou J, Li YS, Chien S. Shear stress-initiated signaling and its regulation of endothelial function. Arterioscler Thromb Vasc Biol. 2014; 34(10): 2191-2198.

7. Dong JF. Cleavage of ultra-large von Willebrand factor by ADAMTS-13 under flow conditions. $J$ Thromb Haemost. 2005; 3(8): 1710-1716.

8. Owens AP 3rd, Mackman N. Microparticles in hemostasis and thrombosis. Circ Res. 2011; 108(10): 1284-1297.

9. Cui Y, Zheng L, Jiang $M$, Jia R, Zhang X, Quan Q, Du G, Shen D, Zhao X, Su W, Xu H, Huang L. Circulating microparticles in patients with coronary heart disease and its correlation with interleukin-6 and C-reactive protein. $\mathrm{Mol}$ Biol Rep. 2013; 40(11): 6437-6442.

10. Wang Y, Zhang S, Luo L, Norström E, Braun OÖ, Mörgelin M, Thorlacius $H$. Platelet-derived microparticles regulates thrombin generation via phophatidylserine in abdominal sepsis. $J$ Cell Physiol. 2018; 233(2): 1051-1060.

11. Vasina E, Heemskerk JWM, Weber C, Koenen RR. Platelets and platelet-derived microparticles in vascular inflammatory disease. Inflamm Allergy Drug Targets. 2010; 9(5): 346354.

12. Storozhuk BG, Pyrogova LV, Chernyshenko TM, Kostiuchenko OP, Kolesnikova IM, Platonova TM, Storozhuk OB, Storozhuk LO, 
Bereznitsky GK, Tsap PYu, Masenko OO, Makogonenko EM, LugovskoyEV. Overall hemostasis potential of the blood plasma and its relation to some molecular markers of the hemostasis system in patients with chronic renal disease of stage VD. Ukr Biochem J. 2018; 90(5): 60-70.

13. Pyrogova LV, Chernyshenko TM, Kolesnikova IN, Platonova TN, Bereznitsky GK, Makogonenko YM, Lugovskoy EV. Level of overall hemostasis potential in donor and patient plasma in pathology. Ukr Biochem J. 2016; 88(2): 56-65.

14. Lugovskoi EV, Kolesnikova IN, Lugovskaya NE, Litvinova LM, Gritsenko PG, Gogolinskaya GK, LyashkoED, Kostyuchenko EP, Remizovsky GA, Pedchenko VN, Komisarenko SV. Quantification of D-dimer and soluble fibrin in blood plasma of people with ischemic heart disease and hypertension. Ukr Biokhim Zhurn. 2004; 76(6): 136-141. (In Russian).

15. Lugovskoi EV, Kolesnikova IN, Lugovskaya NE, Gritsenko PG, Litvinova LM, Gogolinskaya GK, Lyashko ED, Kostyuchenko EP, Golota VI, Kurochka VV, Komisarenko SV. Soluble fibrin and D-dimer at normal pregnancy and pregnancy with risk of miscarriage. Ukr Biokhim Zhurn. 2006; 78(4): 120-129. (In Russian).

16. Makogonenko EM, Kirpa SA, Lugovskoi EV, Nazarenko NA, Kudinov SA. Kinetics of gluand lys-plasminogen activation by the tissue activator in a fibrin clot. Biokhimiia. 1987; 52(10): 1746-1752. (In Russia).

17. Robbie LA, Booth NA, Croll AM, Bennett B. The roles of alpha 2-antiplasmin and plasminogen activator inhibitor 1 (PAI-1) in the inhibition of clot lysis. Thromb Haemost. 1993; 70(2): 301306.

18. Huebner BR, Moore EE, Moore HB, Stettler GR, Nunns GR, Lawson P , Sauaia A, Kelher M, Banerjee A, Silliman CC. Thrombin Provokes Degranulation of Platelet $\alpha$-Granules Leading to the Release of Active Plasminogen Activator Inhibitor-1 (PAI-1). Shock. 2018; 50(6): 671-676.

19. Rühl H, Berens C, Winterhagen A, Müller J, Oldenburg J, Pötzsch B. Label-Free Kinetic Studies of Hemostasis-Related Biomarkers
Including D-Dimer Using Autologous Serum Transfusion. PLoS One. 2015; 10(12): e0145012.

20. Strickland DK, Medved L. Low-density lipoprotein receptor-related protein (LRP)mediated clearance of activated blood coagulation co-factors and proteases: clearance mechanism or regulation? J Thromb Haemost. 2006; 4(7): 1484-1486.

21. Bagoly Z, Ariëns RAS, Rijken DC , Pieters M, Wolberg AS. Clot structure and fibrinolysis in thrombosis and hemostasis. Biomed Res Int. 2017; 2017: 4645137.

22. Weisel JW, Litvinov RI. The biochemical and physical process of fibrinolysis and effects of clot structure and stability on the lysis rate. Cardiovasc Hematol Agents Med Chem. 2008; 6(3): 161-180.

23. Diamond SL. Systems analysis of thrombus formation. Circ Res. 2016; 118(9): 1348-1362.

24. Suenson E, Bjerrum P, Holm A, Lind B, Meldal M, Selmer J, Petersen LC. The role of fragment X polymers in the fibrin enhancement of tissue plasminogen activator-catalyzed plasmin formation. J Biol Chem. 1990; 265(36): 22228-22237.

25. Page EM, Ariëns RAS. Mechanisms of thrombosis and cardiovascular complications in COVID-19. Thromb Res. 2021; 200: 1-8.

26. Nilsen DW, Brosstad F. Discrepant elimination of fibrin des-AA and des-AABB in man. Thromb Haemost. 1986; 55(3): 439.

27. Nilsen DW, Brosstad F, Holm B, Kierulf P, Gravem K, Godal HC. Thrombus-related uptake and vascular clearance of 131 I-fibrin des-AABB as compared to $125 \mathrm{I}$-fibrinogen in patients with established venous thrombosis. Thromb Haemost. 1984; 51(2): 165-168.

28. Nilsen DW, Brosstad F, Holm B, Kierulf P, Godal HC. Clearance characteristics of des-AA fibrin and des-AABB fibrin, and thrombusrelated uptake of des-AABB fibrin as compared to fibrinogen. Scand J Clin Lab Invest Suppl. 1985; 178: 115-119.

29. Rajagopalan S, Pizzo SV. Characterization of murine peritoneal macrophage receptors for fibrin(ogen) degradation products. Blood. 1986; 67(5): 1224-1228. 